\title{
PROCESS OF TECHNOLOGY TRANSFER FOR PUBLIC RESEARCH INSTITUTIONS: A PROPOSAL TO EMBRAPA AND THE POULTRY PRODUCTION CHAIN
}

\author{
Processo de Transferência de Tecnologia para Instituições Públicas de Pesquisa: Uma Proposta \\ para a Embrapa e para Cadeia Produtiva de Aves
}

\begin{abstract}
The process of knowledge and technology transfer has represented a big challenge for public institutions. In these institutions, research is financed with public resources. However, several studies point to a low degree of adoption of the technologies generated by the target audience, which may result in the loss of the relevance of these institutions to the society. This paper aims to propose a model of poultry technology transfer process for Embrapa, the largest and main Brazilian agricultural research company. The methodology involved a qualitative and documentary approach along with a bibliographic research and interviews with agro-industry agents, and researchers from Embrapa and from the Agricultural Research Service. The data show that, although Embrapa develop technologies for the poultry production chain, the adoption rate of these technologies by the poultry chain is very low. It was also diagnosed that there is a gap between the institution and the various links of the chain. The proposed TT model was approved by the interviewed participants who work in the chain and also by representatives of the entities linked to this chain. This acceptance demonstrates the willingness of Embrapa to approach the poultry chain, and to look for joint solutions to existing problems.
\end{abstract}

Nadia Solange Schmidt

Empresa Brasileira de Pesquisa Agropecuária

nadia.schmidt@embrapa.br

Christian Luiz da Silva

Universidade tecnológica Federal do Paraná

christiansilva@utfpr.edu.br

Recebido em: 04/10/2016. Aprovado em: 20/04/2018.

Avaliado pelo sistema double blind review

Avaliador científico: Renato Silvério Campos

DOI: $10.21714 / 2238-68902018 v 20 n 1 p 015$

\section{RESUMO}

O processo de transferência de tecnologia (TT) representa um grande desafio para as instituições públicas. Nessas instituições, as pesquisas são financiadas com recursos públicos. Todavia, diversos estudos apontam para um baixo grau de adoção das tecnologias geradas, por parte do público-alvo, o que pode resultar na perda da relevância dessas instituições perante a sociedade. Este trabalho objetiva propor um modelo de processo de TT avícola, para a Embrapa - a maior e principal empresa brasileira de pesquisa agropecuária. A metodologia envolve uma abordagem qualitativa, pesquisa documental e bibliográfica e entrevistas semi estruturadas. Os resultados mostram que, embora a Embrapa desenvolva tecnologias para a referida cadeia, a taxa de adoção dessas tecnologias é muito baixa. Também disgnosticou-se que existe uma lacuna entre a instituição e os diversos elos da cadeia. O modelo de TT proposto foi aprovada pelos agentes entrevistados, que trabalham na cadeia, bem como por representantes das entidades ligadas a esta cadeia. Esta aceitação demonstra a necessidade de uma maior intereação entre a Embrapa e a cadeia na busca de soluções conjuntas para os problemas existentes.

Palavras-chave: Ciência e Tecnologia, Avicultura Industrial, Adoção de Serviços e Produtos.

Keywords: Science and Technology, Industrial Poultry, Adoption of Services and Products.

\section{INTRODUCTION AND PURPOSE}

Brazil is essentially an agricultural country and agro-industries compose its main economic activities. Among the chains that comprise the Brazilian agroindustries, poultry production is distinguished because of its socio-economic importance. Introduced in Brazil in the 1950 s, the poultry production spread and consolidated rapidly, mainly due to the use of advanced technologies, which increased the competitiveness of the sector, becoming one of the main production chains of Brazilian agro-industries, and positioning Brazil, in 2014, as the largest exporter of the world and the third largest producer of chicken meat (ABPA, 2015). The technology has been 
identified as one of the main contributors to the increase of competitiveness. As a result, companies that comprise many links in this chain have permanently sought new technologies to remain competitive either in domestic or world market (Wang; Chu; Wu, 2007). Agricultural technology transfer of public research system to the private system is considered a complex process because the Public Research Institutions (PRIs) need to bring the benefits of public research to users, influence the direction of technology development and increase research funds through licensing revenues and at the same time, fulfilling its mission with limited resource (Rubensteinand \& Heisey, 2005).

It is also important to consider that simple technology movement does not achieve the success of Technology Transfer (TT), but it requires an effective process and infrastructure that helps technology breaking down barriers. Accordin to Jefferson et al. (2017), Research and Development includes creative work carried out systematically, using accumulated knowledge to increase the stock of knowledge in science and technology, developing new applications. A definition of search results refers comprehensively to the valuable knowledge generated in the research process that becomes accessible to the public. However, it is not easy to define which search results will turn into business because each company has different goals that lead to several results.

Usually, the purpose of the development for which a public research institution is sought lies on achievement items such as patents and publications, because the R \& D activity is aimed at expanding the search results. However, technology transfer, with the aim of creating profits using the search results, places more value on marketing and royalties obtention (Jefferson et al., 2017).

In this context, Schaun (1981), Wildner, Nadal and Silvestro (1993), state that one of the limiting factors regarding the adoption of generated technologies is the way technology is transferred and the possibility of the generated technology not being associated with the reality of the social system to be modified due to the lack of integration between researchers and user. This situation may result from a poorly formulated research problem; users do not face the problem that researchers assumed and thus the generated technology is useless to them (Fujisaka, 1994).

The complexity of public-private TT process becomes even more evident in organized production chains, as in the case of the poultry production chain, which has several suppliers, is segmented by activity and showed high technological development in the past decades. This segmentation and the strong technological development has created a more complex transfer process to the Public Research Institutes (PRIs) operating in this chain. Despite efforts employed by PRIs to solve social problems, promote new knowledge, incorporating the existing advances and searching technological independence, there is a clear challenge to Brazilian PRIs in order to gather around this chain, aiming at reducing this dependence. This challenge is faced by Embrapa, which is the largest Brazilian agricultural research company and has a special research unit dedicated to the development of research and technology solutions for the poultry production chain. The objective of this research was to carry out an assessment of the TT process, evaluating the contribution and role of "Embrapa Swine and Poultry" for the poultry production chain. Based on these results, a TT process model for poultry production chain applicable to this institution was also proposed.

\section{TECNOLOGY TRANSFER: CONCEPTS AND MECHANISMS}

The term "technology transfer" was created in the United States in 1940 and examples of TT can be traced to the advent of the technology itself. Formal studies of TT began with research and dissemination of technology held by European social scientists and quickly gained acceptance in various disciplines as an important research area (Rogers, 1995). Technology transfer has been the subject of studies by various researchers. For example, Eveland (1986) defined it as: "the movement of communication technology through a channel, an individual or an organization to another". Blakeney (1989), on the other hand, describes TT as "the process by which a technology is commercially widespread" (Blakeney 1989:136).

Johnson, Gatz, and Hicks (1997) tried to interpret the TT through a holistic approach that included both the technology movement from the point of origin to the place of use as issues relating to final acceptance and use of technology of the end user. They argued that recognizing the end users needs and the context where the technology is used is essential to TT success. More recently, new TT concepts were created; Rogers, Takegami and Yin (2001) described it as a special type of communication process.

The Association of University Technology Managers (AUTM) defines TT as a process of transferring 
scientific findings from one organization to another for the purpose of developing and marketing (AUTM, 2013), assuming an economic and social benefit promoted by TT. The technology transfer process occurs from the moment an invention or innovation can be shared between different organizations, whether private or public. According to Braga Jr., Pio and Antunes (2009), there are three different ways to make TT process, which are defined by the National Technology Transfer Center (NTTC) (1999) as: - Active form: a person or a group is responsible to check the possibilities of using a particular technology and if it is able to meet market needs.

- Semi active form: its function is to help the technology receiver to identify the best available technology for his business. In this case, a TT agent gives support.

- Passive form: the receiver examines the more appropriate technology through the contact with whom developed it, examining R\&D results.

In addition to these different TT forms, different mechanisms might be applied to TT between public institutions and industries according to their motivations and available resources. Taking as reference, the studies and settings established by NTTC (1999) and by Lee and Win (2004) are: Academic exchanges, conferences, publishing; Consulting and services; Exchange programs; $\mathrm{R} \& \mathrm{D}$ Joint venture; Research cooperative agreement; Licensing; Research contract; Technological or incubators; Academic spin-off; Spin-off technology; Spin-on technology; Dual-use technology.

Nevertheless, to put into effect the above-mentioned mechanisms, it is necessary to define management models that enable their operation.

Public institutions working in the area of S\&T are social sectors held by a society that believes, somehow, it gets or it will get return on the public funds invested. These institutions have a social responsibility to be accountable for the use of resources and contribute to the evolution of the society through the actions of its members who may, in addition to divulge the knowledge produced, be active in incorporating science in the daily life. In the opinion of Geller (2010), one must consider that scientific advances alone will not solve the problems of humanity, but can help improve certain political, social and economic conditions. Therefore, it is essential to widely disseminate the priority scientific issues to the society, so that citizens have elements to provide feedback and to influence rationally in situations that affect their lives. However, in the case of public research institutions, it is not enough to just communicate the scientific results. It is necessary to find an efficient way to transfer them to users (Schmidt Bassi et.al, 2014).

\section{TECHNOLOGY TRANSFER FROM THE PUBLIC TO THE PRIVATE SECTOR}

According to Jefferson (2017), Public Institutions and Research are designed to mobilize academic knowledge and findings, transforming them into products with broad impact in society. Some benefits of the publicprivate relationship include more productive relationships between academia and industry; greater willingness of government funding agencies to support joint research proposals; and royalty income from license agreements covering search results.

However, despite the potential TT financial benefits, these returns rarely generate sufficient revenue to recover the initial research investment that resulted in the technologies in question. For example, recent research has found that more than half of the US technology transfer programs bring less money than the operating costs of the program and only 16 percent are financially self-sustaining (Abrams et al., 2009). Thus, the social function of an IPP comprises its most important contribution.

While it may be difficult to describe all forms of dissemination of public knowledge - including publications, conference presentations and consulting - in an institutional technology transfer policy, the underlying motivation for all knowledge transfer activities should be part of its institutional mission (Jefferson, 2017).

Agricultural activities have been widely developed by public institutions and Universities because such activities generally have little market value. Physical products were not being produced and technologies were considered "public goods" that anyone could use (PINEIRO, 2007). However, since the late 1970s, this scenario has changed. The technologies have turned into physical products, such as agricultural machinery or pesticides. The exponential growth in industries led to a rapid expansion of private companies that create, manufacture and sell technology (Rubenstein \& Heisey, 2005, Pineiro; 2007).

Public research institutes play an important role in creating innovative technology for development, but, in most cases, these institutions cannot successfully market it. This is a very critical factor for governments, which allocate public resources to research. In this context, an efficient way to manage the Government-subsidized Research, Development and Innovation process is to 
maximize efficiency for both the development and commercialization of the technology generated (LIM et al., 2016).

Lee and Win (2004) conducted a study aiming at identifying the main motivations between the actors and the TT, at the industrial sector and at public research institutes and also in developed countries. The results of this survey are described in Table 1.

The process of technology transfer is complex and the simple movement of technology to a new environment does not achieve success, it requires the development of a process and infrastructure technology that helps to break down existing barriers. In this context, Johnson, Gatz and Hicks (1997) point out that technology is not autonomous, but encompasses political, economic, social and cultural values that can serve as barriers to its diffusion (Table 2). In some cases, technology is needed so that the end user will help break the barriers of technology. Moreober, technologies need to be "pushed" through the maze of barriers to the end user. The degree of desire of users towards technology will determine whether the technological potential constraints will prevail, and the speed with which innovation will go from the original source to the end user.

TABLE 1 - TT motivations between the actors that help TT process in PRIs and Companies

\begin{tabular}{|c|c|}
\hline PRIs advantages that help TT process to industry & Industry advantages that help TT process to PRIs. \\
\hline $\begin{array}{l}\text { Access opportunities to the economy needs and develop their } \\
\text { activities in accordance with them. }\end{array}$ & $\begin{array}{l}\text { Better-qualified graduates with relevant training that meets the } \\
\text { needs of the company. }\end{array}$ \\
\hline Opportunity to exchange students in industry. & Access to training facilities that can assist in the project. \\
\hline Company access to develop basic and applied research. & Enter the premises of Universities and knowledge of its staff. \\
\hline Access to protected markets. & Access to University research and their data collection. \\
\hline Improvement in the implementation of new technologies. & Reduction in production delay. \\
\hline Creation of a "good neighbor" environment. & $\begin{array}{l}\text { Improving the public image of the industry and attracting } \\
\text { talented students. }\end{array}$ \\
\hline Patents. & Knowledge gains. \\
\hline $\begin{array}{l}\text { Participation in the development of new products and } \\
\text { spin-offs. }\end{array}$ & $\begin{array}{l}\text { Obtaining new technological services and quality } \\
\text { improvement, new markets. }\end{array}$ \\
\hline
\end{tabular}

Source: Lee and Win (2004)

TABLE 2 - The main barriers to technology transfer process

\begin{tabular}{|c|c|}
\hline Type of barries & Descripton \\
\hline Economic and financial & The determining factor is associated with the return on investment. \\
\hline Technical & $\begin{array}{l}\text { The ability to change management and planning of resources for the implementation of new } \\
\text { technology }\end{array}$ \\
\hline Social & $\begin{array}{l}\text { The transfer occurs within a social system that defines the limits within which the technology is } \\
\text { transferred and disseminated. An individual does not recommend a technology that he thinks bad or } \\
\text { has few benefits. }\end{array}$ \\
\hline Personal & $\begin{array}{l}\text { The transfer depends on the end-user features. A small percentage of the population constantly seeks } \\
\text { innovations and is followed by a larger group called early adopters. This is the key group to be } \\
\text { identified by the agents of TT. }\end{array}$ \\
\hline Cultural & $\begin{array}{l}\text { We must consider the labor force characteristics and the available server resources, the region or the } \\
\text { host country. }\end{array}$ \\
\hline Environmental & $\begin{array}{l}\text { The main barriers are the natural resources and environmental risks, combined with the lack of } \\
\text { planning. }\end{array}$ \\
\hline Political & One of the main barriers is the regulation for the TT can be implemented plausibly. \\
\hline Market b & $\begin{array}{l}\text { There are six main sources: economies of scale, product differentiation, capital requirements, } \\
\text { changing costs, access to distribution channels and cost disadvantages comparative scale. }\end{array}$ \\
\hline
\end{tabular}

Source: Johnson, Gatz and Hicks (1997)

Organizações Rurais \& Agroindustriais, Lavras, v. 20, n. 1, p. 15-29, 2018 


\section{MODELS OF TECHNOLOGY TRANSFER}

Several TT models have been developed and used over the years. Each model has a different approach, focused on an application that is suitable to meet its goal. However, all models have focused on the identification and understanding of their elements through steps or goals or even direction: innovation, implementation or commercialization of technology developed.

According to Sung and Gibson (2005), the three most prominent are: a) The Appropriability Model which emphasizes the importance of quality research and competitive market pressure on TT achievement; the model assumes that "good technology sells itself", what is rarely true in the real world; b) The Dissemination Model - which focuses on the diffusion of innovation; the goal is to disseminate innovations for individual users; and c) The Knowledge Utilization Model - the most common in practice, which emphasizes the importance of interpersonal communication of researchers and users; barriers and transfer organizational facilitators. However, this model tends to reduce a very complex process for chronologically organized steps.

\section{TECHNOLOGY TRANSFER AT AGRICULTURAL RESEARCH SERVICE (ARS)}

The agricultural research service (ARS) is linked to the United States Department of Agriculture (USDA). It was created in 1953 to find solutions to agricultural problems that affect Americans. We chose to study the TT model of this institution by the fact that it develops research activities very similar to Embrapa. In addition, the poultry production chain model in Brazil follows the American model, including the same suppliers of inputs and genetics. It has 8,000 employees, including 2,200 researchers. Its budget in 2013 was US \$ 1.131 billion.

The information was obtained through interviews and semi-structured questionnaires applied to 4 managers of the TT office and 3 ARS researchers from March to June 2014.

Regarding the TT process, ARS has a Technology Transfer Office (TTO), which performs the statutory functions, administers patent licensing program for researches conducted by USDA, and helps move research outcomes to the market. Thus, that office conducts the entire TT process. The mechanisms used in this process are formal agreements or scientific activities, presentation of papers in technical meetings, scientific publications, patenting, and licensing. The technologies developed by ARS are licensed for production and marketing for interested private sector partners and the researchers who developed the technology receive royalties on commercialization. Future users of new technologies or processes developed by ARS are consulted when a company asks to conduct a search and when the research idea involves commercial value. Interaction with the future user also occurs during annual scientific meetings, formal and informal presentations and through informal communication.

Market needs are constantly monitored and considered when preparing research proposal. Although ARS develops basic research, the main focus of both the research and TT is the innovation with the development of commercial products. The research is directed not only to solve real problems, but also to transfer these solutions to stakeholders. The institution uses the reverse search model in which the research projects are designed from the identified demand, which directly affects the form of TT since there is no need to search for generated technology users. Therefore, TT actions aim at formalizing agreements and transfer contracts as well as the distribution of royalties.

These features presented in TT models are meant to facilitate the identification and understanding of their steps, components and goals, and each model has its originality. However, some models were shown to have the same direction toward the innovation, implementation and marketing of the developed technology. It can be assumed that most of these models highlights the importance of the interaction between the developer of the technology and the potential user.

It is known that many of these models are focused on TT in private institutions, whose characteristics differ from public institutions, mainly on the availability of financial resources and marketing to reach the market. While private institutions destine much of its budget for sales and marketing departments, in most of the public institutions this department does not even exist. Therefore, public institutions should adopt a TT model that allows them to facilitate the transfer process with the minimum possible cost, ie, developing technology in partnership with the future users. In this context, as ARS is also a public research institute similar to Embrapa, the transfer model utilized by ARS has characteristics and mechanisms that could also be adopted by Embrapa in its TT process. 


\section{BRAZILIAN POULTRY PRODUCTION CHAIN}

According to Freitas, Bertoglio and Nunes (2002), during the 1950s and 1960s the Agroindustrial Complex emerged, in which various production steps are interconnected in search of uniformity and continuity of processes, usually coordinated by a larger Unit, which is responsible for planning and controlling smaller units. In this context, the Brazilian Poultry Complex, which is connected to other major sectors such as the feed industry, pharmaceutical chemical industry, machinery and equipment industry and supermarket chains, has emerged (Freitas; Bertoglio; Nunes, 2002).

Sorj et al. (2008) declare that the integration model widely used across the country has brought new dynamic to the sector that is driven by large slaughterhouses and intense government support. From the 1980s, the poultry production chain showed a significant transformation, characterized by productivity gains, opening of new markets and the consolidation of the organization in the chain, with a further integration of their links (SILVA; SAES, 2005a). According to Embrapa Swine and Poultry (2013), in the 1990s, agro-industries went into the era of competitiveness in which technological restructuring, efficiency, lower costs and administrative restructuring of companies have become survival strategies. The achievement of foreign markets was able thanks to sanitary quality of our herds. On the other hand, the significant improvement of population income in recent years has been boosting domestic consumption of the product (Empresa Brasileira, 2013).

According to the Brazilian Association of Animal Protein (ABPA, 2015), in 2014, Brazilian production of chicken meat was 12.69 thousand tons, maintaining the country in the position of largest exporter of the world and third largest producer of chicken meat, behind the United States and China. From the total broiler production in 2014, $67.70 \%$ was destined for domestic consumption and $32.30 \%$ for export. The total export volume was 4,099 thousand tons, exported to over 150 countries, contributing with $40 \%$ of the world market for poultry meat. The industrial poultry sector employs directly and indirectly more than 5 million people, and accounts for almost $1.5 \%$ of Gross Domestic Product (GDP). This chain is represented by thousands of integrated producers, hundreds of processing companies and dozens of exporters, which highlights its importance for the country (APBA, 2015) and can be divided into three steps (Silva; Saes, 2005b): production, processing and distribution and consumption:
Production begins in grandparent flocks belonging to multinational companies. Eggs are imported from grandparent flocks, which produce the next generation of birds, called the parent breeders. The parent breeders produce chicken flocks whose meat is processed for human consumption. Egg incubation from parent is performed in hatcheries (SILVA and SAES, 2005b). In the breeding process and incubation of chicks, there is a set of chemical and pharmaceutical inputs as well as suitable equipment, feed, supplies and medicine (SILVA; SAES 2005b).

Industrialization starts from the chicken slaughter, with an average age of 42 days which after slaughtering will be sold whole, in parts, or even processed as fast or embedded dishes, which adds more value to its price and allows the product differentiation process (SILVA; SAES, 2005b). The abattoirs operate as the leading wholesalers of cold, frozen or processed broiler.

Distribution and consumption, which consists of two forms of marketing: domestic or foreign market, with the possibility of direct sales to the wholesale and from the wholesale to small retail to resale; through the distributor and from him to supermarkets and small retailers and direct sales to large customers (SILVA; SAES, 2005b). During the production process, manufacturing and distribution of the final product, there are other sectors that produce and supply technology, research and genetic development, equipment, medicine, feed and inputs and transport to complete broiler production chain.

\subsection{Technological Changes in Broiler Chain}

The industrialization of the Brazilian poultry industry, which took place in the 1960s and 1970s, was a milestone for the early adoption of technologies in industrial poultry process. During this period, Brazil imported US industrial model through the acquisition of poultry hybrid strains, machinery, equipment, and genetics. The advance in this chain is linked to the technological development regarding the process that started using technologies directed to flexible production for industrial products. According to Belusso and Hespanhol (2010), from the 1970s, there were several structural changes in broiler production in relation to genetics, nutrition, automation and lifting scales. Between the 1960s and 1980 s, research was focused on the evaluation of hatching eggs, hatching rate and feed conversion, and from the 1990s researches were directed to increase yield of broiler noble cuts, adding value into it. To better illustrate where 
innovations occurred in the industry, we will present the technological innovations in three segments of broiler chain: production inputs, industrialization and marketing/ distribution.

Regarding production inputs, three main activities prevail in order to supply materials to industry: nutrition, animal health, and genetics (Santini; Souza, 2005).

Advances in nutrition, according to Santini (2006), have contributed substantially to the development of poultry genetics, decreasing growth time of poultry and improving their performance. Technological innovations in this activity are related to the use of maize varieties with high oil content and the use of pelleted feed to increase weight gain.

Technological innovations in animal health are related to prebiotics, probiotics, acidifiers and enzymes. Probiotics are used as an alternative for traditional additives (veterinary drugs), and enzymes are used to increase the digestibility of feed nutrients or to reduce the antinutritional effects. The development of products against coccidiosis was also pointed out by Santini (2006) as a promising area in poultry production.

Regarding genetics, Santini (2006) points out that the need of genetic material imports is decreasing in the last years in Brazil, because the country is multiplying the genetic material within the country.

In the industrialization segment, the development of value-added products is observed (Santini, 2006). The automatic control technologies increased feed conversion of broilers. Setters and hatchers equipped electronically allow controlling broiler development. Table 3 summarizes the main technological changes regarding products and process in nutrition, genetics, animal health and poultry processing.

As for the marketing and distribution segment, according to Jesus Junior et al. (2007), the great expansion of broiler production and export led the largest industries to search for internationalization of their operations by building new plants or acquiring existing plants.

Research carried out by Alves (2003) shows that the main poles responsible to generate poultry technological innovations are in the stages of production and industrialization, where the companies of nutrition, genetics, health, machinery and equipment and agricultural industries are located. Alves (2003) points out that the main segments of the innovative centers of the industrial poultry sector act in internationalized markets and oligopolistic market structure.

Innovations generated in the production links are mostly directed and absorbed by the manufacturing sector, which in turn performs innovation processes and products, which are transferred to consumers in the form of a new or improved product that can be accepted by the consumer, becoming an innovation. However, consumers reveal their preferences, especially in terms of new products or improved products, which are caught by agroindustries and from the knowledge of these preferences. They try to find a way to meet consumers demand, alone or in partnership with other links. Whereas innovations occur more strongly in the stages of production and manufacturing; research efforts are also concentrated in these two sectors.

TABLE 3 - Major technological changes in products and processes in the areas of nutrition, genetics, animal health and poultry processing

\begin{tabular}{|c|c|c|}
\hline Segment & Technological changes in products & Technological changes in processes \\
\hline Nutrition & $\begin{array}{l}\text { Replacing components; feed without meat by- } \\
\text { products; organic mineral products; changes in } \\
\text { packaging. }\end{array}$ & $\begin{array}{l}\text { Automation of production functions: reception of raw } \\
\text { materials and dosages; precision balances; mills; mixers; } \\
\text { packing. }\end{array}$ \\
\hline Genetics & $\begin{array}{l}\text { Feed Conversion; meat and breast yield; } \\
\text { decrease of fat content; disease resistance; } \\
\text { conformity; warpage. }\end{array}$ & $\begin{array}{l}\text { Selection markers; Quantitative Genetics, ultrasound, } \\
\text { x-rays; techniques in breeding and rearing: temperature, } \\
\text { light and moisture control, feed distinction. }\end{array}$ \\
\hline Animal health & $\begin{array}{l}\text { Additives for isolated and combined use with } \\
\text { feed; natural feed additives; mycoplasmosis } \\
\text { vaccine; probiotics. }\end{array}$ & $\begin{array}{l}\text { Automation of processes: reverse osmosis water system; } \\
\text { liquid distillation; packaging; lyophilizer; fermenters; } \\
\text { precision balances; chromatographs. }\end{array}$ \\
\hline Processing & $\begin{array}{l}\text { Sausages and similar products sliced into smaller } \\
\text { packages; seasoned cuts and disposed in trays; } \\
\text { ready meals; new packaging design. }\end{array}$ & $\begin{array}{l}\text { Implementation of automated systems for defeathering and } \\
\text { scalding; evisceration; cooling processes; classification and } \\
\text { weighing; freezing tunnels. }\end{array}$ \\
\hline
\end{tabular}

Source: Santini, 2006

Organizações Rurais \& Agroindustriais, Lavras, v. 20, n. 1, p. 15-29, 2018 


\section{EMBRAPA: CHARACTERISTICS AND SCOPE OF ACTIVITY}

The Brazilian Agricultural Research Corporation - Embrapa - was created on April 26, 1973, with the basic functions of implementation research, development and innovation, and their transfer to the production environment. It operates through 17 Administrative Units and 46 Research or Service Units, called Decentralized Units (DUs), present in almost all Brazilian states, the most diverse biomes. It also operates in North America, Europe, Asia, Africa and Latin America, through virtual laboratories and projects.

Embrapa coordinates the National Agricultural Research System (NARS), consisting of federal public and state institutions, universities, private companies and foundations that, in a cooperative manner, perform researches in different geographical areas and fields of scientific knowledge. Its staff totalized 9,790 employees in 2012. Of this total, 2,444 are researchers. The budget of the company in 2014 was $\mathrm{R} \$ 2.6$ billion.

\subsection{Embrapa Swine and Poultry}

Embrapa Swine and Poultry is a research unit of Embrapa and its mission is "to facilitate research, development and innovation solutions for sustainability of the swine and poultry industry for the benefit of the Brazilian society" (Embrapa Swine and Poultry, 2011). Established on June 13, 1975, as National Swine Research Center, in 1978 it received the duty to research hens, changing its name to the National Research Center for Swine and Poultry, which is now called Embrapa Swine and Poultry, located in Concórdia/SC. It currently has a staff of 210 employees, from which 51 are researches and $86 \%$ hold Ph.D. and 14\% hold master degree.

\subsection{The process of technology transfer at Embrapa Swine and Poultry}

The TT strategies at the institution are developed $\mathrm{i}$ $\mathrm{n}$ a decentralized manner, directly by the Research Units, since Embrapa does not have a policy of TT to guide this process. Thus, the Research Units develop their own TT strategies, according to what they believe to be the most appropriate. This fact has its advantages, considering that the unit has a much broader knowledge of their target audience and hence more efficient channels to communicate with them.

Structurally, the unit has a TT Deputy, which coordinates the sectors of Articulation and Implementation of TT Program, responsible for dealing with TT agents in order to elaborate TT projects and programs, development and execution of business contracts, and Prospecting Technology Assessment. It also analyzes ex-ante impacts of technologies and research projects and promotes socioeconomic and environmental analysis of the generated technologies. Its aim is also the impact assessment and the adoption level of the generated technologies; support the development of actions for the implementation of government policies and programs; guide the intellectual property registration of the process technologies generated by this Embrapa Unit (Embrapa Suinos Aves, 2015).

The types of used contracts are of technical cooperation - where technology is developed in partnership with private companies, use of licensing and/ or commercialization of technologies - when technology is developed only by the this Embrapa Unit, which transfers it to the partner market, paying royalties on sales.

\subsection{Embrapa Swine and Poultry activities towards broiler production chain}

To analyze the TT process of Embrapa Swine and Poultry, semi-structured questionnaires were applied to different agents. The objective was to know the perception of these actors on the performance of Embrapa Swine and Poultry along the broiler production chain.

\subsubsection{Point of view from the professionals of agro-industries}

Researches conducted by Embrapa Swine and Poultry are strongly focused on solving the problems of this sector. Thus, these professionals were interviewed in order to know their perception. They act in strategic positions in the three largest Brazilian agro-industries.

The main sources of technology in this sector are the suppliers, national public institutions and private ones, besides technicians. All agro-industries have the structure of R\&D and develop their own research, with national and foreign Universities, public institutions and foreign experts. These partners are mainly chosen by the credibility, confidence, knowledge and competence. According to the survey, the factors that hinder public institutions partnerships are the slowness and bureaucracy. Regarding the use of technologies developed by Embrapa Swine and Poultry, only one representative of an agroindustry said that he uses the generated technologies, while others have merely stated that in the past they used the technology, and currently they use the knowledge that is made available by the institution. In general, Embrapa

Organizações Rurais \& Agroindustriais, Lavras, v. 20, n. 1, p. 15-29, 2018 
contribution expected by agro-industries is to be close (ease of access) to the sector, in order to develop practical solutions and assist in the development of guidelines for poultry sector.

\subsubsection{Point of view of the professionals from the industrialized chain and production chain links}

From the results obtained from the actors of agroindustries, it was assumed to expand the research to know the perception of business professionals engaged in the links in the agro-industry, equipment companies, genetics, nutrition and health. A total of 142 professionals answered the questionnaires.

The perception of these actors was very similar to that of agro-industries. Most companies (66.67\%) have $\mathrm{R} \& \mathrm{D}$ structure and conducts research in order to test and develop new products. The main sources of innovation of these links are the national universities, public institutions and suppliers, chosen for their knowledge, credibility and trust. As already stated for agro-industries, the slowness and bureaucracy were also cited as factors that hinder partnerships with public institutions. Regarding the Embrapa Swine and Poultry contribution to the chain, in general, respondents recognized that the institution has contributed to it. However, $80.53 \%$ of respondents noticed a large gap between the institution and the sector. To reduce this gap, respondents suggest that the institution should promote regular meetings with chain representatives to discuss the demands, since its role, according to the interviewees, is to develop technologies to meet these demands.

\subsubsection{Point of view of TT professionals from Embrapa Swine and Poultry}

Nine employees who work in Technological Prospecting and Evaluation Sector and also in Technological Articulation and Implementation Sector were interviewed.

According to most respondents, TT strategies are not clearly defined and when drawn, they are punctual, directed to specific projects and discussed without the TT professionals, which often results in the communication of results, not transferring the outcomes to the target audience. Respondents suggested that to enhance the TT process of the institution, there is a need for effective participation of the TT team in preparing the strategies to further transfer the results of research projects. Moreover, the need for a new TT model that minimizes the distance between Embrapa and the broiler production chain and the low adoption rate of technologies developed by Embrapa was also mentioned. They suggest the use of a tool that can identify chain demands and, from there on, allow the development of more applied technologies that meet the chain demands.

\subsubsection{Point of view of Poultry Researchers from Embrapa Swine and Poultry}

In order to know the perception of poultry researchers about the institution role and its contribution towards the chain, semi-structured interviews were conducted with 16 researchers from Embrapa Swine and Poultry.

The contribution of Embrapa Swine and Poultry for broiler the production chain is diversely perceived by the respondents. Six respondents assume that the Unit has contributed more in the past, especially in the 19701990 period, and currently, the contribution is limited and is losing importance. Others believe that the Unit contributes to the advancement in all chain segments, but could contribute more and more efficiently. In the opinion of researchers, credibility and trust are factors that help formalizing partnerships, while slowness, bureaucracy, lack of human resources, lack of focus, of autonomy of researchers and effective TT action, product offering and research outcomes that do not meet the chain demands. The lack of knowledge and insertion of the staff in the production chain are hindering factors in partnerships with chain actors.

Regarding the transfer of technologies developed by the Unit, the problems identified were: technologies with little practical applicability, TT process failures, little interaction between the institution and the private sector. It was also mentioned that many technologies are disclosed until completely validated. Moreover, many technologies that are already customary in the chain or there is no interest in them are still produced. There is a strong perception that generated technologies had good impact in the past but they are rapidly losing importance. In addition, perception is lacking about what is useful and what is not useful and research outcomes are usually made available through scientific papers and not finished products. It became clear that the TT problem is not focused on tools or techniques used, but largely in the technologies that are being developed and made available.

\section{METHODOLOGY}

As methodology, a case study was carried out involving a qualitative approach, documentary and 
bibliographic research and interviews using semistructured questionnaires. The survey was conducted in three steps. In the first step, a diagnosis of the Technology Transfer (TT) Process, the contribution and also the role of poultry production chain were accomplished. In this step, bibliographical and documentary research was used, besides semi-structured interviews with professional of different links of broiler production chain, researchers from the Agricultural Research Service - ARS. Moreover, a total of 211 researchers, managers and technology transfer professionals from Embrapa Swine and Poultry were interviewed from May 2013 to September 2014.

In the second step, the model was developed for poultry TT process to be applied at Embrapa. In this step, documentary and bibliographic research were performed and the information obtained in the interviews was analyzed. The third step consisted in validating the proposed model by 142 professionals from different knowledge areas. They were specialized in genetics, animal health, nutrition, equipments, and agro-industries from broiler production chain.

The production and industrialization segments of the productive chain of broilers were chosen due to the fact that they are the most innovative chain links. The population, according to Malhotra (2012), is the totality of the elements that have some common set of characteristics of interest for a given study. It can be understood as the "[...] universe for which the researcher intends to generalize the results of the research" (FERRARESI, 2010, p.74). In the case of this research, the number of elements of this population is high, and it is necessary to reduce the number of elements to characterize a sample. (MARCONI, LAKATOS, 2007).

Random searches in which all elements are equally likely to be selected were applied. Santos (2014) indicates that the calculation of the simple random sample is given by the formula:

$$
n=\frac{N * z^{2} * p(1-p)}{z^{2} * p(1-p)+e^{2} *(N-1)}
$$

n: calculated sample

$\mathrm{N}$ : population

z: standardized normal variable associated with the confidence level

p: probability of the event

$e$ : sample error
The sample error attributed to the calculation was $5 \%$, with a confidence level of $95 \%$ for a population of 190 people. In this case, the desired sample number is 128 . The number of respondents was 142, higher, than the desired sample number. The population was divided into five chain links: Agroindustries, equipment, genetics, nutrition and sanitation. The number of actors of each link varies according to the number of companies selected from the register used. The population and the number of questions answered and answered in each link were: Health 38 (22); Nutrition 66 (52); Genetics 13 (12); Equipment 37 (29); Agroindustries 36 (27).

In relation to the respondent companies, 50.3\% are internationally active and $35 \%$ are large companies (with more than 500 employees). As to the profile of the interviewees, $54.54 \%$ were managers, $20.20 \%$ were directors or presidents, and the others were analysts $(6.6 \%)$ and technicians $(20.20 \%)$. The issues addressed in the interviews are described in Table 4.

Statistical analyzes were carried out using the SPSS software (Statistical Package for the Social Sciences) v. 21, IBM SPSS Amos v. 21.0.0 and Microsoft Excel in the evaluation stages of the data collected. In an attempt to assign greater credibility to the answers obtained through the application of validation questionnaires, a hypothesis test named Chi-square was applied. This study was undertaken through a semi-structured questionnaire, which was sent to Lime Survey software, from January 02nd to March 20th, 2015.

\section{ELABORATION AND VALIDATION OF A TECHNOLOGY TRANSFER MODEL FOR THE BRAZILIAN POULTRY PRODUCTION CHAIN}

The proposed model was created considering: bibliographic studies, interviews with the actors of the areas already mentioned and TT model of Agricultural Research Service (ARS), because it is a very similar institution to Embrapa. Several authors point out the absence of a link between researchers and company professionals and the need for a closer relationship between the public research institutes and companies (Krieger; Galembeck, 1990; Schwartzman, 2002; Kim, 2005; Póvoa, 2008, among others). Futhermore, arrange the public research institutes to work more tightly with the sectors that need the findings of their research, what was supported by the various respondents of the poultry chain.

The main assumption of the proposed model is to increase the interaction between the technology developers and the users, suggesting the technology as a result of a two-way interactive process (non-linear) with

Organizações Rurais \& Agroindustriais, Lavras, v. 20, n. 1, p. 15-29, 2018 
constant and simultaneous exchange of ideas between the involved individuals. The observatory objective is acting as facilitator of interaction and integration between Embrapa Swine and Poultry, researchers, broiler production chain agents and other institutions in attracting technological demands, besides providing space for demands discussion and formalizing partnerships to attend them. This interaction might occur either through an online discussion platform or as regular meetings to be held in each chain link.

Briefly, the purposes of the observatory are: a) to identify poultry production chain demands and alternatives to solve them; b) to promote integration between Embrapa Swine and Poultry and the poultry production chain through cooperative projects; c) to carry out prospecting opportunities in RD\&I; d) to create an enabling environment for information exchange between the various chain actors and the researchers from Embrapa Swine and Poultry and; e) to encourage the formalization of partnerships between actors.

As a public institution, Embrapa Swine and Poultry mission is focused on attending common chain demands. Nevertheless, identifying these demands is not always easy, given the chain complexity and size. Therefore, it is imperative that the Observatory team develop maintain strong and impartial interaction with the various chain actors, in order to follow technological development and identify research demands. At the same time, it must interact with the institution RD\&I team in order to search for alternatives, solutions and suggestions, compared to the identified needs, which will be analyzed to verify the possibility of attendance. Figure 1 illustrates the proposed model.

TABLE 4 - Interviewees and questions

\begin{tabular}{|c|c|}
\hline Interviewed & Issues covered (summary) \\
\hline $\begin{array}{l}\text { TT managers from Embrapa } \\
\text { Headquarters }\end{array}$ & $\begin{array}{l}\text { Strategies for TT developed by Embrapa, TT instruments used, participation of the } \\
\text { UDs in the process, process efficiency, process improvements }\end{array}$ \\
\hline Embrapa TT Training Coordinator & $\begin{array}{l}\text { Who is Embrapa's customer, articulation between the different demands, prioritization } \\
\text { of demands, expectation of demand, translation of demand, how the solution is taken } \\
\text { to the client, evaluation of the effectiveness of the solution, existence of a standard TT } \\
\text { model, TT for Embrapa, Embrapa approach with the productive sector, evaluation of } \\
\text { UDs by TT results. }\end{array}$ \\
\hline $\begin{array}{l}\text { TT Office Managers and ARS } \\
\text { Researchers }\end{array}$ & $\begin{array}{l}\text { Financing of research projects, clients, type of relationship, ARS assessment by society, } \\
\text { barriers affecting ARS performance, prioritization of research, management of research } \\
\text { projects, participation of users in the development of technologies, strategic planning, } \\
\text { type of research developed, patenting, TT mechanisms and strategies, strengths and } \\
\text { weaknesses of the process, number of technologies transferred per year, importance of } \\
\text { TT. }\end{array}$ \\
\hline Actors of Agribusiness & $\begin{array}{l}\text { Sources of innovation, benchmarking, type of innovation in the chain, type of } \\
\text { R \& D carried out, chain problems, future challenges, existence of partnerships, } \\
\text { partner selection criteria, partnerships with IPPs, use of Embrapa Pigs and Poultry } \\
\text { technologies, forms of Embrapa's contribution to the chain. }\end{array}$ \\
\hline $\begin{array}{l}\text { Researchers from the poultry sector of } \\
\text { Embrapa Pigs and Poultry }\end{array}$ & $\begin{array}{l}\text { Role of Embrapa Pigs and Poultry, prioritization of research, factors that facilitate } \\
\text { and hinder the interaction of Embrapa with the chain, Embrapa contribution to chain, } \\
\text { transfer of generated technologies. }\end{array}$ \\
\hline $\begin{array}{c}\text { Professionals of Embrapa TT Pigs and } \\
\text { Poultry. }\end{array}$ & $\begin{array}{l}\text { Target audience of Embrapa's research, interaction with the public, strategies and } \\
\text { tools of TT, strategy planning, strategy efficiency, availability of research results, and } \\
\text { improvements in the process. }\end{array}$ \\
\hline $\begin{array}{l}\text { Professionals from the links of } \\
\text { agribusiness, genetics, nutrition, } \\
\text { equipment and sanity }\end{array}$ & $\begin{array}{l}\text { Characterization of the respondent and the company, sources of innovation, instruments } \\
\text { in the search for innovation, R \& D activities, partnerships, criteria for choosing the } \\
\text { partners, which should innovate, Brazilian R \& D structure and innovation in the chain, } \\
\text { type of innovation in Embrapa's contribution to the chain, research efforts, difficulties } \\
\text { in the partnership with IPPs, IPP forms developed efficient technologies, creation of } \\
\text { observatory, the role of Embrapa and the companies in the observatory, participation of } \\
\text { the links, interaction formalization and participation in the observatory }\end{array}$ \\
\hline
\end{tabular}

Source: Authors

Organizações Rurais \& Agroindustriais, Lavras, v. 20, n. 1, p. 15-29, 2018 


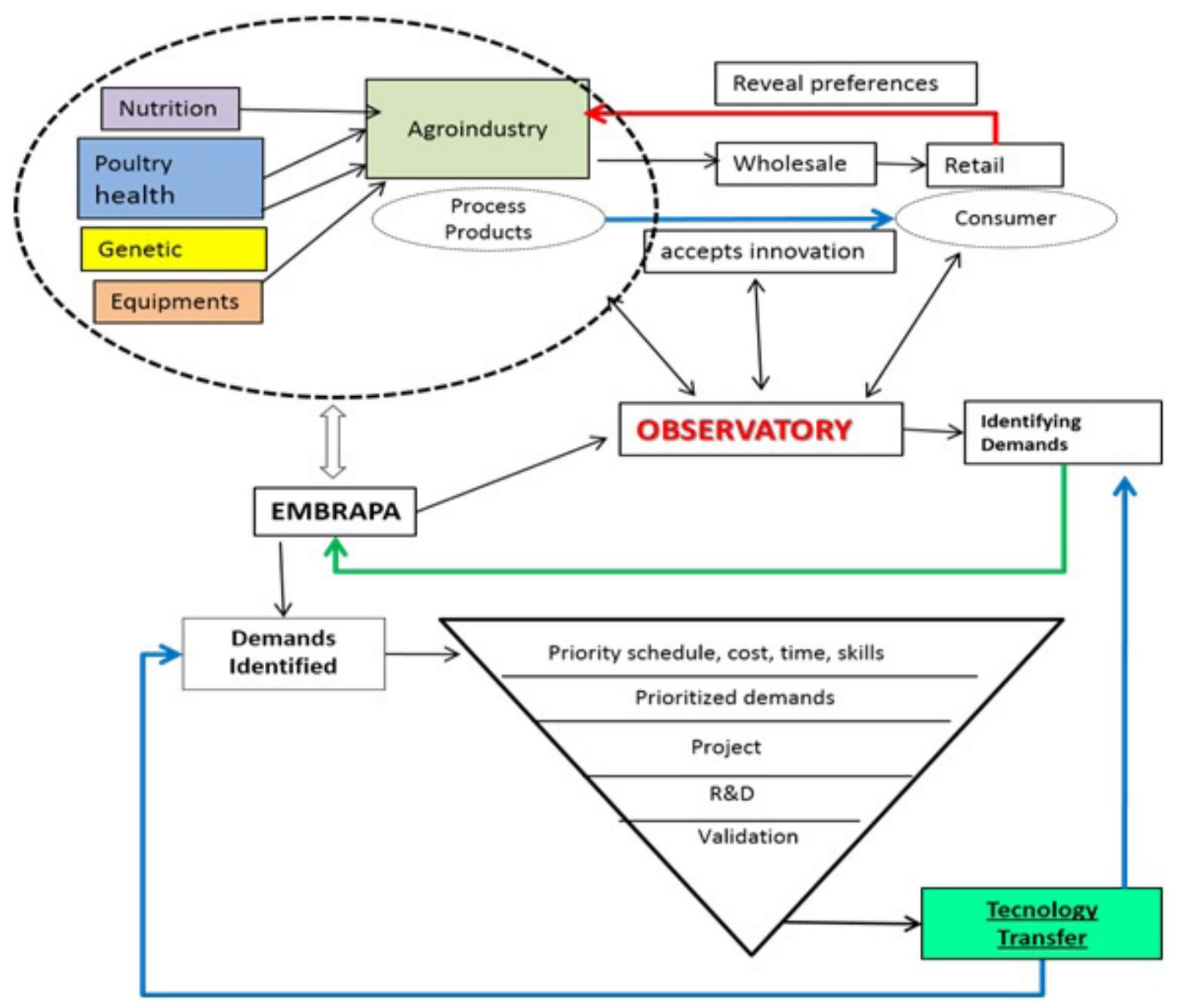

FIGURE 1 - Proposed technology transfer model (Observatory)

Source: Own authorship (2015)

Once identified, the demands will be priorized taking into account the institution strategies, courses, time, technical capacity, competences and cooperative potential for research development. If approved, the next step will be the development and validation of results, and later the transfer of the generated technology. With the adoption of this model, TT role will be similar as that developed by the ARS Office. In other words, consulting clients, formalizing partnerships, distributing royalties (whenever the case) and patent and/or licensing of technology. Assuming that research projects are developed to meet specific demands or solve a specific problem of the user, TT role will no longer be the search of demands identification mechanisms or customers/ users of the generated Technologies. The adoption of this model saves time, financial and human resources as well as increase effectiveness of the institution towards the chains, with the development of technologies directed to meet their real demands.

The proposed model was validated with 142 actors of various links: nutrition, genetics, equipment, animal health and agro-industries and was approved by $96.77 \%$ of respondents who expressed interest in participating in an active way in the observatory. 


\section{CONCLUSIONS}

The adoption of this model provides advantages for both Public Research Institutes and the poultry production chain. The main advantages are: the optimization of human and financial resources (for both), since the research will be conducted in partnership, sharing the risks and results; better use of public resources, considering that these will be applied in research projects focused on effective solutions to broiler chain (no longer "shelf research"), greater agility in identifying and developing research and a greater institutional legitimacy towards broiler chain. In the long term, the development of joint research, focused to meet the identified demands may contribute to the reduction of foreign technological dependence, now present in broiler production chain.

If Embrapa Swine and Poultry aims to improve its relevance towards the poultry production chain, it will have to implant a faster system to meet the demands (lowering dramatically the time between the demand identification and the delivery of results). Otherwise, research and private technology will occupy completely the acting space of this chain. The use of the proposed model may assist the institution to pursue this agility.

This research was limited to studying the process of technology transfer between Embrapa Suinos and Aves and the productive poultry chain, with the aim of proposing a participatory TT model. Further research is suggested on how to implement the proposed model.

\section{REFERENCES}

ABRAMS, Irene.et al. How are U.S. technology transfer offices tasked and motivated-Is it all about the money? Research. Management Review, no17, v.1, p.1-34, 2009.

ALVES, João M. De S. Prospecção tecnológica na indústria avícola gaúcha. 2003. Disponível em:<HTUhttp://www.fee.tche.br/eeg/artigos/MESA $\% 20$ 10\%20ALVES.docUTH>. Acesso em: 19.jun.2013.

ASSOCIAÇÃO BRASILEIRA DE PROTEÍNAANIMAL (ABPA). Relatório Anual 2016. Available in: <http:// abpa-br.com.br/setores/avicultura/publicacoes/relatoriosanuais $>$. Acess in: 22 jan. 2016.

THE ASSOCIATION OF UNIVERSITY TECHNOLOGY MANAGERS (AUTUM) 2013. Available in: $<$ http://www. autm.net/Home.htm>. Acess in 07 de apr. 2014.
BELUSSO, Diane.; HESPANHOL, Antonio N. A evolução da avicultura industrial brasileira e seus efeitos territoriais. Revista Percurso - NEMO, vol.2, no.1, p. 25-51, 2010.

BLAKENEY, Michael. Legal aspects of technology transfer to developing countries, Oxford, ESC, 1989.

EMPRESA BRASILEIRA DE PESQUISA AGROPECUÁRIA (EMBRAPA). Available in: <http:// www.embrapa.br/>. Acess in: 03. Nov.2013.

EMBRAPA SUÍNOS E AVES. Available in: <http://www. cnpsa.embrapa.br>. Acess in 20.oct.2015.

EVELAND, John D. Diffusion, technology transfer and implementation. Knowlegde, creation, diffusion e utilization, vol.8, no 2, p.312-322, 1986.

FERrARESI, Alex,A. Gestão do Conhecimento, Orientação para o Mercado, Inovatividade e Resultados Organizacionais: Um estudo em empresas instaladas no Brasil. 2010. 213f. Tese (Doutorado em Administração) - Programa de Pós-graduação em Administração, Universidade de São Paulo, São Paulo, 2010 .

FREITAS, Luiz A. R.; BERTOGLIO, Oscar; NUNES, Osmar M. A tecnologia na avicultura industrial brasileira. In: Proceedings 22rd Encontro Nacional de Engenharia de Produção, pp.1-8, Curitiba: Brazil, 2002.

FUJISAKA, Sam. Learning from six reasons why farmers do not adopt innovationsintended to improve sustainability of upland agriculture. Agricultural Systems, vol.46, n ${ }^{\circ} .4$, pp.409-425, 1994.

JEFFERSON, David, J et al.Technology transfer in the Americas: common and divergent practices among major research universities and public sector institutions. J Technol Transf. no. 42, p.1307-1333, 2017.

JESUS JUNIOR, Celso et al. A Cadeia da Carne de Frango: tensões, desafios e oportunidades. BNDES Setorial, $n^{\circ}$ 26, p.191-232, 2007.

JOHNSON, Scott D.; GATZ, Elisabeth F.; HICKS, Don. Expanding the Content Base of Technology Education: Technology Transfer as a Topic of Study. Journal of Technology Education, vol.8, nº 2, 1997. 
KIM, Linsu. Da imitação à inovação: a dinâmica do aprendizado tecnológico da Coréia. Unicamp, 388 p. 2005.

KRIEGER, Eduardo; GALEMBECK, Fernando. A capacitação brasileira para a pesquisa. In: Ciência e tecnologia no Brasil. SCHWARTZMAN, Simon; Bertero, Carlos O.; Krieger, Eduardo M. et. al. (eds). Vol.3. Rio de Janeiro: Editora da Fundação Getúlio Vargas, 1996.

LEE, Jungown.; WIN, Hnin. N. Technology transfer between university research centers and industry in Singapore. Technovation, vo.24, n ${ }^{\circ}$ 5, p.433-442, 2004.

LIM, Injong, et al. An Analysis and Improvement Strategy of the Technology Transfer Efficiency for Public Research Institutes. International Journal of Software Engineering and Its Applications. No.12, v.10, p. 227-238, 2016. http://dx.doi.org/10.14257/ ijseia.2016.10.12.19 ISSN: 1738-9984 IJSEIA.

MARCONI, Marina, A.; LAKATOS, Eva, M. Técnicas de pesquisa. São Paulo: Atlas 6 ed. 2007.

NATIONAL TECHNOLOGY TRANSFER CENTER (NTTC) Available in: < http://www.nttc.edu/>. Acess in: Nov. 2015.

PINEIRO, Martin. Agricultural technology transfer to developing countries and the public sector. Available in: file://D:/perfil/Documents/Documentos\%20outro\%20 perfil/bibliografia $\% 20$ por $\% 20$ assunto/foresight/ Agricultural\%20technology $\% 20$ transfer $\% 20$ to $\% 20$ developing $\% 20$ countries $\% 20$ and $\% 20$ the $\% 20$ public $\% 20$ sector.htm Acess in: 25 set. 2013.

PÓVOA, Luciano M.C. Patentes de universidades e institutos públicos de pesquisa e a transferência de tecnologia para empresas no Brasil. Tese (doutorado) - Universidade Federal de Minas Gerais, Belo Horizonte, 2008.

ROGERS, Everett M. Diffusion of innovations. 4 ed. New York: Free Press, 1995.

ROGERS, Everett M.; TAKEGAMI, Shiro; YIN, Jing. Lessons learned about technology transfer. Technovation, vol.21, nº, p.253-261, 2001.
RUBENSTEIN, Kelly, D; HEISEY, Paul,W. Can Technology Transfer Help Public-Sector Researchers do More with Less? The Case of the USDA's. Agricultural Research Service, AgBioForum, vol.8, $\mathrm{n}^{\circ} 2$ and 3, p.134142, 2005.

SANTINI, Giuliana A. Dinâmica tecnológica da cadeia e frango de corte no Brasil. Análise dos segmentos de insumo e processamento. Tese (Doutorado) Universidade Federal de São Carlos, São Carlos, 2006.

SANTINI, Giuliana A.; SOUZAFILHO, Hildo M.Inovação tecnológica em sistemas agroindustrial: a avicultura de corte no Brasil. In: Gestão do Agronegócio. BATALHA, MarcosO. São Carlos, EdUFSCar, 2005.

SANTOS, Glauber Eduardo de Oliveira. Cálculo amostral: calculadora on-line.2015. Disponível em: <http://www. calculoamostral.vai.la $>$. Acesso em: 20 mar.2015.

SCHAUN, Nicolau M. Difusão de tecnologia no Centro Nacional de Milho e Sorgo. Sete Lagoas: Embrapa CNPMS, 27 p, 1981.

SCHMIDT BASSI, Nadia, S. et al . Controversies about the Process of Technology Transfer from Public Research Institutions in Brazil: The Case of the Brazilian Agricultural Research Corporation - Embrapa. Journal of Technology Management \& Innovation, Santiago , v. 9, n. 3, p. 182-195, 2014 . Disponivekl em <http:// www.scielo.cl/scielo.php?script=sci_arttext\&pid=S0718$27242014000300014 \& \operatorname{lng}=\mathrm{es} \& \mathrm{n} r \mathrm{~m}=\mathrm{iso}>$. Acesso em: 26 dez. 2017. http://dx.doi.org/10.4067/S07182724201400030001

SCHWARTZMAN, Simon. A pesquisa científica e o interesse público. Revista Brasileira de Inovação, vol.1, $\mathrm{n}^{\circ} 2$, p.361-395, 2002.

SILVA, Christian L; SAES, Maria.S. M. Estruturas e características da cadeia de valor a partir do tipo de governança: uma avaliação preliminar da avicultura de corte paranaense. Informe Gepec, vol.9, n ${ }^{\circ}$, p.1-16, 2005a.

SILVA, Christian. L.; SAES, Maria S. M. A Questão da Coexistência de Estruturas de Governança na Economia dos Custos de Transação: Evidências Empíricas na avicultura de corte Paranaense. Revista de AdministraçãoMackenzie, vol.6, no 3, p.88-118, 2005b. 
SORJ, Bernado; POMPERMAYER, Malory; CORADINI, Odacir L. Camponeses e Agroindústria. Transformação social e representação política na avicultura brasileira. (On line). Centro Eldestein de Pesquisa Sociais. Rio de Janeiro, 102p., 2008.

SUNG, Tae K.; GIBSON, David. V. Knowledge and technology transfer: key factors and levels. In: Proceedings Of 4th International Conference On Technology Policy And Innovation, 441-449. Curitiba: Brazil, 2000.

SUNG, Tae; GIBSON, David V. Knowledge and technology transfer grid: Empirical assessment.
International Journal of Technology Management, vol.29, no 3/4, p.216-230, 2005.

WANG, Ling; Chu, J.; WU, Jiang. Selection of optimum maintenance strategies based on a fuzzy analytic hierarchy process. International Journal of Production Economics, vol.107, $\mathrm{n}^{\circ}$ 1,p.151-163, 2007.

WILDNER, Leandro, P.; NADAL, Raul; SILVESTRO, Milton. Metodologia para integrar a pesquisa, a extensão rural e o agricultor. Agropecuária Catarinense, vol.6, $\mathrm{n}^{\circ}$ 3, p.37-47, 1993. 